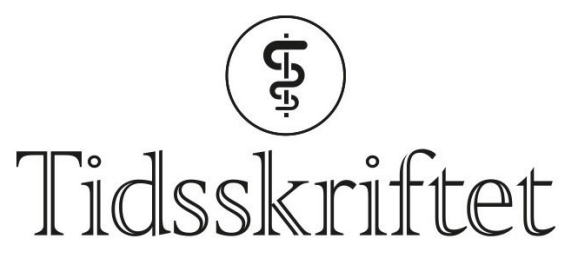

DEN NORSKE LEGEFORENING

\title{
Skal vi skrinlegge begrepet statistisk signifikans?
}

MEDISIN OG TALL

\section{MATS JULIUS STENSRUD}

E-post: m.j.stensrud@medisin.uio.no

Mats Julius Stensrud er lege, dr.philos. og statistiker. Han er Fulbright-stipendiat ved Harvard School of Public Health og jobber ellers som postdoktor ved Avdeling for biostatistikk, Universitetet i Oslo. Forfatteren har fylt ut ICMJE-skjemaet og oppgir ingen interessekonflikter.

\section{ODD O. AALEN}

Odd O. Aalen er professor emeritus i statistikk ved Avdeling for biostatistikk, Universitetet i Oslo. Forfatteren har fylt ut ICMJE-skjemaet og oppgir ingen interessekonflikter.

Leger gjør beslutninger på usikkert grunnlag. Statistikk er det formelle verktøyet for å belyse usikkerheten, og begrepet statistisk signifikans brukes mye i den medisinske faglitteraturen. Men nå går hundrevis av forskere til opprop for å få begrepet fjernet. 


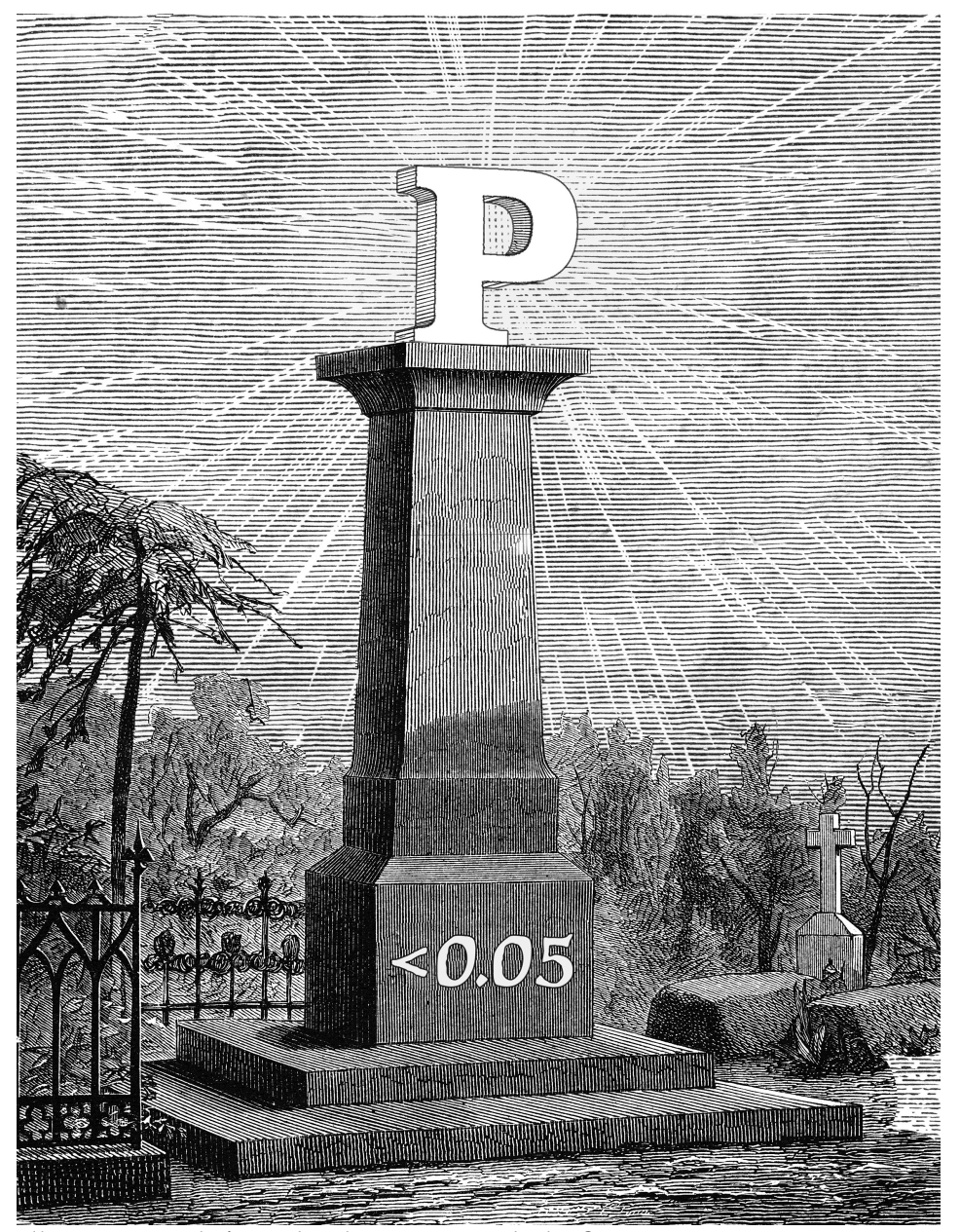

Illustrasjon: clu/iStock, tilpasset av Tidsskriftet

Formålet med begrepet statistisk signifikans er å beskytte mot falske resultater og å sikre reproduserbarhet. I praksis brukes statistisk signifikans gjerne for å beskrive en hypotesetest som ga en p-verdi mindre enn o,05. Dette er for øvrig en vilkårlig grense som like gjerne kunne vært lavere, for eksempel o,o1.

\section{Kobrafenomenet}

Det er få som er uenig i at falske resultater og manglende reproduserbarhet er et problem. Likevel er det flere som mener at den omfattende bruken av begrepet statistisk signifikans er en dårlig løsning $(1,2)$. Noen sammenlikner det med et kobrafenomen, og refererer til det britiske imperiet: Britene var bekymret over de mange giftige kobraslangene i Dehli, India, og vedtok derfor å gi pengepremier i bytte mot døde kobraer for å redusere bestanden. I stedet for å ta livet av de ville kobraene var det mange som tjente store penger på å avle frem kobraer. «Løsningen» gjorde altså situasjonen verre, fordi insentivet ble misbrukt.

\section{Dikotomani og p-fisking}

Et nøkkelproblem med statistisk signifikans er den såkalte dikotomanien: p-verdier brukes ofte til å lage kunstige todelinger, slik at en p-verdi mindre enn o,05 tolkes som en reell effekt og en p-verdi større enn 0,05 tolkes som ingen effekt. Dette er en klar misforståelse av p-verdien. I det hele tatt skyldes nok mange av problemene med begrepet statistisk signifikans at p-verdier feiltolkes (3), også blant redaktører og fagfellevurderere i ledende medisinske tidsskrift.

Forhåpentligvis fører opprøret til at redaktører i mindre grad bruker statistisk signifikans som kriterium for å publisere artikler

Et relatert problem er den såkalte $p$-fiskingen (p-hacking): Noen forskere analyserer dataene sine på flere forskjellige måter, men oppgir bare analyser som gir signifikante $\mathrm{p}$-verdier. 
Dette fører selvsagt til overestimering av effektstørrelser og inflasjon i usikkerhetsmål. Vi kan redusere dette problemet ved å registrere alle analyser før studier blir utført. Likevel er det et tilleggsproblem at mange tidsskrifter bare er interessert i å publisere statistisk signifikante funn.

\section{Hva er alternativet?}

Det er ikke opplagt at enten-eller-svar basert på statistisk signifikans er nødvendig i de fleste enkeltstudier. Riktignok må vi ta enten-eller-beslutninger i klinisk praksis, men et statistisk signifikant resultat fra en enkeltstudie er uansett ikke tilstrekkelig for å ta kliniske beslutninger. For eksempel legges det mye vekt på klinisk signifikans i de fleste introduksjonskurs i statistikk - altså hvorvidt en effekt har betydning i klinisk praksis. Den kliniske signifikansen er umulig å vurdere fra en p-verdi alene. Dessuten gir p-verdien ingen informasjon om kvaliteten på studiedesignet og datamaterialet. Selvsagt kan heller ikke pverdien belyse kostnader eller praktiske konsekvenser av en klinisk beslutning.

I stedet for å fokusere på statistisk signifikans bør en medisinsk studie belyse et forskningsspørsmål på så mange måter som mulig, og effektestimater med konfidensintervaller gir nesten alltid mer informasjon enn p-verdier.

\section{Problemet er ikke p-verdien i seg selv}

Når det er sagt, vil vi understreke at p-verdien i seg selv ikke er skyld i problemene med begrepet statistisk signifikans. P-verdien er et veldefinert matematisk uttrykk som beskriver usikkerhet. Problemet er misbruk og mistolkninger av p-verdier. De svarer ikke direkte på spørsmålet om en hypotese er korrekt, og må derfor alltid tolkes i kontekst: En liten p-verdi kan gi god dokumentasjon for en velfundert hypotese, men en liten p-verdi gir også svak dokumentasjon for en lite plausibel hypotese (4).

Noen statistikere mener at bayesianske metoder bør erstatte p-verdiene og konfidensintervallene. Bayesianske beslutningsregler kan imidlertid rammes av det samme kobrafenomenet som statistisk signifikans. Dessuten krever bayesianske metoder at man definerer antagelser om effekter a priori, altså før studien gjennomføres, og disse antakelsene er ofte subjektive.

\section{Konklusjon}

Det er klare problemer med bruken av begrepet statistisk signifikans i medisinsk forskning, og ukritisk bruk av p-verdier har antakelig bidratt til mange ikke-reproduserbare resultater. Derfor belyser årets opprør mot bruken av statistisk signifikans et viktig problem. Forhåpentligvis fører opprøret til at redaktører i mindre grad bruker statistisk signifikans som kriterium for å publisere artikler. Medisinske forskere bør også fokusere mer på effektstørrelser og konfidensintervaller enn p-verdier alene.

LITTERATUR:

1. McShane BB, Gal D, Gelman A et al. Abandon statistical significance. Am Stat 2019; 73: 235-45. [CrossRef]

2. Amrhein V, Greenland S, McShane B. Scientists rise up against statistical significance. Nature 2019; 567:305-7. [PubMed][CrossRef]

3. Greenland S, Senn SJ, Rothman KJ et al. Statistical tests, P values, confidence intervals, and power: a guide to misinterpretations. Eur J Epidemiol 2016;31:337-50. [PubMed][CrossRef]

4. Nuzzo R. Statistical errors: P values, the'gold standard' of statistical validity, are not as reliable as many scientists assume. Nature 2014;136: 150-3. [PubMed][CrossRef] 
Publisert: 2. august 2019. Tidsskr Nor Legeforen. DOI:10.4045/tidsskr.19.0311 (C) Tidsskrift for Den norske legeforening 2020. Lastet ned fra tidsskriftet.no 